\title{
Effect of Tea Catechins on Folate Analysis in Green Tea by Microbiological Assay
}

\author{
Keizo UMEgAKI ${ }^{1}$, Yuki SeKInE ${ }^{1,2}$, Yoko SATO ${ }^{1}$, Tsuyoshi ChIBA ${ }^{1}$ and Masaru SONODA ${ }^{2}$ \\ ${ }^{1}$ Information Center, National Institute of Health and Nutrition, National Institutes of Biomedical \\ Innovation, Health and Nutrition, 1-23-1 Toyama, Shinjuku-ku, Tokyo 162-8636, Japan \\ ${ }^{2}$ Department of Domestic Science, Kyoritsu Women's University, 2-2-1, \\ Hitotsubashi, Chiyoda-ku, Tokyo 101-8437, Japan
}

(Received September 10, 2015)

\begin{abstract}
Summary Green tea is thought to be a primary source of folate in the Japanese diet, based on folate content analyzed by a microbiological assay. Green tea also contains high amount of catechins, in particular, epigallocatechin gallate (EGCg), which was demonstrated to be able to inhibit the digestive enzyme activities and microbial growth in the folate assay. In the present study, we examined whether tea catechins interfered with components of the folate assay for green tea. A marked inhibitory effect of EGCg on microbial growth was observed at an inhibitory concentration of higher than $10 \mu \mathrm{g} / \mathrm{mL}$. Tea catechins without the galloyl moiety did not show an inhibitory effect. EGCg inhibited the activity of the three enzymes used for assay sample preparation at an inhibitory concentration of higher than $750 \mu \mathrm{g} / \mathrm{mL}$ for $\alpha$-amylase, $1,000 \mu \mathrm{g} / \mathrm{mL}$ for protease, and $50 \mu \mathrm{g} / \mathrm{mL}$ for conjugase. However, with each step of the assay, the actual concentration of EGCg was decreased to below the inhibitory concentration of each analytical step. Lack of influence of EGCg on green tea folate assay was confirmed by an addition of folate standard in tea infusion. These results suggested that tea catechins have no practical impact on folate analysis in green tea, using the general microbiological assay.
\end{abstract}

Key Words green tea, food folate, epigallocatechin gallate, microbiological assay

Folate is an important vitamin, and its deficiency can lead to megaloblastic anemia (1). Low folate status leads to an increase in plasma homocysteine, which is a risk factor for cardiovascular disease (1). In addition, low folate status in women of childbearing age leads to an increased risk of fetal abnormalities, such as neural tube defects (1).

Folate in food exists in monoglutamate and polyglutamate forms. Folate naturally occurring in foods ("natural folate") exists mainly in the polyglutamated form, with different chemical structures in the pteridine ring, such as in tetrahydro-, dihydro-, formyl- and 5-methyltetrahydrofolates (2). Synthetic folic acid (pteroylmonoglutamic acid) is the most oxidized and stable form, highly bioavailable, and used for dietary supplements and processed foods. Analysis of these folates in food is critical to estimate the intake amount. Various analytical methods have been presented, such as the microbiological assay, HPLC, and enzyme protein binding assay (3). Among these methods, the microbiological assay can analyze many forms of folates, which include mono-, di- and tri-glutamate derivatives existing in foods (4), and is adopted as the method of choice in the "Standard Tables of Food Composition in Japan”. The microbiological assay procedure is divided into three steps: sample homogenization and dilution with buffer; treatment with digestive enzymes ( $\alpha$-amylase, protease and conju-

E-mail: umegaki@nih.go.jp gase); and finally, addition to growth media for assessment of microbial growth rates $(5,6)$.

Green tea contains natural folate, and was regarded as one of the primary sources of folate in the Japanese diet (7), when folate consumption was estimated by the "Standard Tables of Food Composition in Japan". Additionally, green tea is known to contain catechins, which have antimicrobial activities $(8,9)$, and inhibit various enzymes (10-12). These actions of tea catechins may interfere with green tea folate analysis by the microbiological assay. However, there have been few data reported on the effect of tea catechins on green tea folate analysis by the microbiological assay.

In the present study, we examined whether tea catechins interfered with the microbiological assay for food folates, and investigated the inhibitory concentrations of tea catechins for the assay.

\section{Materials and Methods}

Chemicals. (-)-Epigallocatechin gallate (EGCg), (-)epicatechin gallate (ECg), (-)-epigallocatechin (EGC), $(+)$-catechin $(\mathrm{C})$, and (-)-epicatechin (EC) were purchased from Nagara Science Co., Ltd. (Gifu, Japan); pteroyl- $\gamma$-L-glutamic acid, pteroylhepta- $\gamma$-L-glutamic acid, 5-methyl-5,6,7,8-tetrahydropteroyl- $\gamma$-L-glutamic acid (5-MTHF 1 ) and 5-methyl-5,6,7,8-tetrahydro-pteroylpenta- $\gamma$-L-glutamic acid $\left(5-\mathrm{MTHF}_{5}\right)$ from Schircks Laboratories (Jona, Switzerland); $\alpha$-amylase from Aspergillus oryzae and protease from Streptomyces griseus 


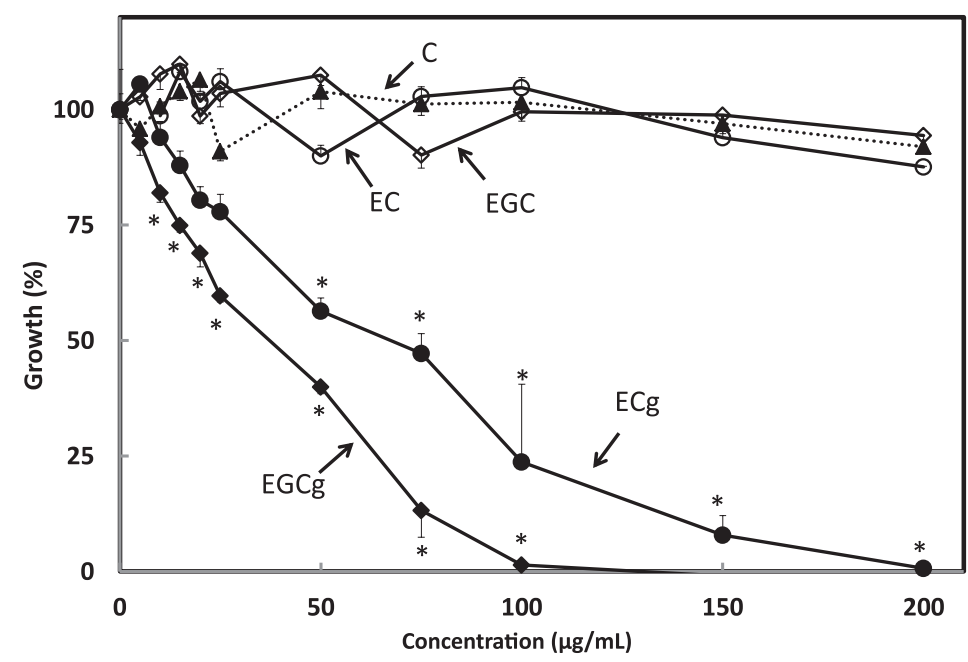

Fig. 1. Dose-dependent inhibition of tea catechins on microbial growth. L. rhamnosus was cultured in a complete folic acid casei medium with various concentrations of tea catechins (EGCg, ECg, EGC, C, EC). Values are mean \pm SE, $n=3$. * Significant difference from the level without catechins.

from Sigma-Aldrich (St. Louis, MO); chloramphenicolresistant Lactobacillus rhamnosus (ATCC 27773) from the American Type Culture Collection (Rockville, MD); folic acid casei medium from Becton Dickinson (Sparks, MD); and rat serum from Nippon Bio-Test Laboratories Inc., Tokyo. Other chemicals were purchased from Wako Pure Chemical Industries, Ltd. (Osaka, Japan). Alphaamylase and rat serum were treated with charcoal to eliminate contaminating folate (6). Tea catechins were dissolved in a small amount of methanol and diluted with the buffer used in the respective assay.

Analytical Methods. The folate microbiological assay was performed using the tri-enzyme method described by Aiso and Tamura (5). In brief, samples were homogenized with 20 fold of $50 \mathrm{mmol} / \mathrm{L}$ potassium phosphate buffer ( $\mathrm{pH}$ 6.2) that contained $0.2 \mathrm{mmol} / \mathrm{L} 2$-mercaptoethanol and $114 \mathrm{mmol} / \mathrm{L} \mathrm{L}$-ascorbic acid. The sample $(250 \mu \mathrm{L})$ was mixed with $250 \mu \mathrm{L}$ of the phosphate buffer and $500 \mu \mathrm{L}$ of $\alpha$-amylase $(10 \mathrm{mg} / \mathrm{mL})$, and incubated for $2 \mathrm{~h}$ at $37^{\circ} \mathrm{C}$. After heating in boiling water for $10 \mathrm{~min}$, the sample was treated with $500 \mu \mathrm{L}$ of protease $(20 \mathrm{mg} / \mathrm{mL})$ for $2 \mathrm{~h}$ at $37^{\circ} \mathrm{C}$. The samples were heated in boiling water for $10 \mathrm{~min}$, centrifuged at $8,000 \times g$ for $10 \mathrm{~min}$, and the resulting supernatant $(250 \mu \mathrm{L})$ was supplemented with $650 \mu \mathrm{L}$ of the phosphate buffer and $100 \mu \mathrm{L}$ of rat serum conjugase, and then incubated for $3 \mathrm{~h}$ at $37^{\circ} \mathrm{C}$. After heating and centrifugation, the supernatant was diluted twice with $1 \%$ L-ascorbic acid, mixed with an equal volume of a complete folic acid casei medium containing $L$. rhamnosus, and cultured in a 96-well plate for $42 \mathrm{~h}$ at $37^{\circ} \mathrm{C}$. Turbidity of the samples was measured at $600 \mathrm{~nm}$. Folate concentration in a sample was expressed as the pteroyl- $\gamma$-L-glutamic acid equivalent.

The tea catechin effect on the growth of L. rhamnosus was determined by the addition of tea catechins (EGCg, ECg, EGC, C, EC) (up to $200 \mu \mathrm{g} / \mathrm{mL}$ ) to a complete folic acid casei medium, and cultured in a 96-well microplate.

The activity of $\alpha$-amylase was determined by the Ber- nfeld (13) procedure using soluble starch as a substrate. Briefly, the reaction mixture consisted of $50 \mu \mathrm{L} 1 \%$ (w/v) starch in $10 \mathrm{mmol} / \mathrm{L}$ phosphate buffer $(\mathrm{pH} 6.9)$ containing $3.35 \mathrm{mmol} / \mathrm{L} \mathrm{NaCl}$, and EGCg (up to $3 \mathrm{mg} /$ $\mathrm{mL}$ ), incubated for $5 \mathrm{~min}$, and then treated with $50 \mu \mathrm{L}$ of $\alpha$-amylase (20 mg/mL) for $10 \mathrm{~min}$ at room temperature. Blank samples for each EGCg concentration were prepared. The enzyme reaction was stopped by adding $50 \mu \mathrm{L}$ of $48 \mathrm{mmol} / \mathrm{L}$ 3,5-dinitrosalicylic acid in 1.06 $\mathrm{mol} / \mathrm{L}$ sodium potassium tartrate and $0.4 \mathrm{~mol} / \mathrm{L} \mathrm{NaOH}$, heated in boiling water for $15 \mathrm{~min}$, followed by cooling to room temperature. After the addition of $500 \mu \mathrm{L}$ of water, absorbance of the sample was measured at $540 \mathrm{~nm}$. Enzyme activity was calculated using maltose as the standard.

Protease activity was determined by the Anson (14) procedure using casein as a substrate. Casein was dissolved in $100 \mathrm{mmol} / \mathrm{L}$ phosphate buffer ( $\mathrm{pH} 7.5$ ) to make a $10 \%(\mathrm{w} / \mathrm{v})$ substrate solution. To $400 \mu \mathrm{L}$ of the substrate, $100 \mu \mathrm{L}$ of $\mathrm{EGCg}$ (up to $9 \mathrm{mg} / \mathrm{mL}$ ) was added and incubated for $5 \mathrm{~min}$ at room temperature, then treated with $100 \mu \mathrm{L}$ of protease $(60 \mathrm{mg} / \mathrm{mL})$ for $10 \mathrm{~min}$ at $37^{\circ} \mathrm{C}$. The reaction was stopped by the addition of $500 \mu \mathrm{L}$ of $1.8 \%(\mathrm{w} / \mathrm{v})$ trichloroacetic acid. The resulting sample was applied to a solid phase extraction column (15), because EGCg in the sample markedly interferes with the protein measurement assay. Caseindegraded product in the elute was determined by the Bradford Protein Assay kit (Bio-Rad Laboratories, Inc., Hercules, CA).

Conjugase activity was determined by the HPLC method previously described by Hasoun et al. (16). Briefly, the reaction mixture consisted of $100 \mu \mathrm{L}$ of $50 \mu \mathrm{mol} / \mathrm{L} 5-\mathrm{MTHF}_{5}, 700 \mu \mathrm{L}$ of $50 \mathrm{mmol} / \mathrm{L}$ phosphate buffer (pH 7.0) containing $114 \mathrm{mmol} / \mathrm{L} \mathrm{L}-\mathrm{ascorbic}$ acid and $0.2 \mathrm{mmol} / \mathrm{L} 2$-mercaptoethanol, and $100 \mu \mathrm{L}$ of EGCg (0 to $15 \mathrm{mg} / \mathrm{mL}$ ), incubated for $5 \mathrm{~min}$, and then treated with $100 \mu \mathrm{L}$ of rat serum conjugase for $4 \mathrm{~h}$ at $37^{\circ} \mathrm{C}$. The reaction was stopped by heating in boiling 
a) a-Amylase
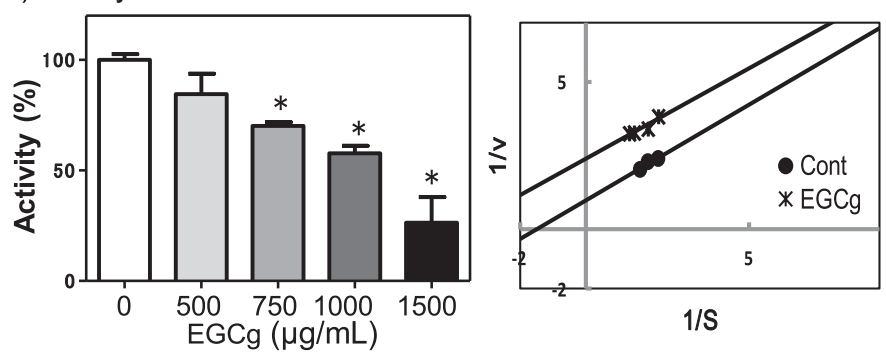

b) Protease
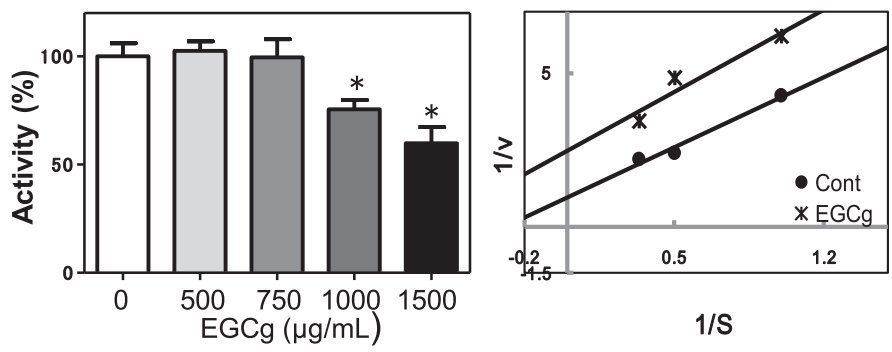

c) Conjugase
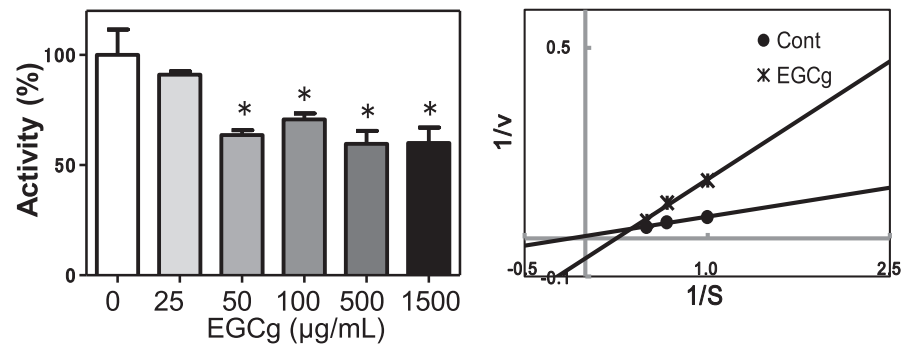

Fig. 2. Dose-dependent inhibition of EGCg on $\alpha$-amylase in a), protease in b), conjugase in c) and Lineweaver-Burk plot. The activities of the three enzymes used in the folate assay were determined with various concentrations of EGCg. In the Lineweaver-Burk plot, $1.5 \mathrm{mg} / \mathrm{mL}$ of EGCg was used. S and V indicate substrate concentration and reaction velocity. Values are mean \pm SE, $n=4{ }^{*}$ Significant difference from the level without EGCg.

water for $10 \mathrm{~min}$. After centrifugation at 10,000 $\times g$ for $10 \mathrm{~min}$, the supernatant was applied to a solid phase extraction column to eliminate the EGCg, as described in the protease assay section. The eluted samples containing $5-\mathrm{MTHF}_{1}$ were applied to a HPLC device equipped with a fluorescence detector (excitation $295 \mathrm{~nm}$, emission $356 \mathrm{~nm}$ ) (16).

For the estimation of the inhibitory action of EGCg on enzyme activities, $\alpha$-amylase, protease, and conjugase were assayed with different concentrations of each substrate in the presence of EGCg $(1.5 \mathrm{mg} / \mathrm{mL})$ and a Lineweaver-Burk plot was calculated. Changes in actual concentration of EGCg during each of the analytical steps were determined by a HPLC device equipped with an ultraviolet detector at $230 \mathrm{~nm}$. The initial content of EGCg in the green tea model sample was set at $670 \mathrm{mg} / 100 \mathrm{~mL}$. HPLC was performed with a Shimadzu HPLC-VP system (Shimadzu Corporation, Kyoto, Japan). The sample was applied to an L-column ODS, $4.6 \times 250 \mathrm{~mm}, 5 \mu \mathrm{m}$ particle size (Chemical Inspection \& Testing Institute, Tokyo, Japan), at $40^{\circ} \mathrm{C}$, and eluted with a linear gradient of $5 \%$ acetonitrile containing $0.1 \%$ phosphoric acid (A) and $50 \%$ acetonitrile containing $0.1 \%$ phosphoric acid (B). The gradient protocol was 0-5.0 min, 5\% B; 5.1-10 min, 5-10\% B; 10.1-15 min,
$10 \% \mathrm{~B} ; 15.1-25 \mathrm{~min}, 10-20 \% \mathrm{~B}$ at a flow rate of $1.2 \mathrm{~mL} / \mathrm{min}$. Tea catechins in diluted samples were also analyzed by HPLC with electrochemical detection (17).

Green tea infusion sample was prepared from tea leaves (gyokuro) purchased from a local grocery store. Concentration of typical tea catechins in the green tea infusion was as follows: $\mathrm{EGCg}, 158 \mathrm{mg} / 100 \mathrm{~mL}$; EGC, $158 \mathrm{mg} / 100 \mathrm{~mL}$; $\mathrm{ECg}, \quad 13 \mathrm{mg} / 100 \mathrm{~mL}$; $\quad \mathrm{EC}$ $36 \mathrm{mg} / 100 \mathrm{~mL}$; C, $3 \mathrm{mg} / 100 \mathrm{~mL}$. Folate analysis in the green tea infusion was performed with and without tri-enzyme treatment. Folate analysis in the green tea infusion was also performed by the addition of a known amount of folate standard: either pteroyl- $\gamma$-L-glutamic acid or pteroylhepta- $\gamma$-L-glutamic acid was added to the green tea infusion at concentration of $31.1 \mu \mathrm{g} / 100 \mathrm{~mL}$ or $37.7 \mu \mathrm{g} / 100 \mathrm{~mL}$, respectively.

Statistical Analyses. Data are presented as the mean \pm standard error (SE). Data were analyzed by oneway analysis of variance followed by Dunnett's multiple comparison test. Values of $p<0.05$ were considered significant.

\section{Results}

Effect of tea catechins on microbial growth

EGCg and ECg showed marked inhibition of micro- 
Table 1. Changes in actual EGCg sample concentration during digestive enzyme treatments.

\begin{tabular}{lcc}
\hline Treatment steps & $\begin{array}{c}\text { EGCg concentration } \\
(\mu \mathrm{g} / \mathrm{mL})\end{array}$ & \% of initial value \\
\hline Homogenization & 322 & $100 \%$ \\
$\alpha$-Amylase & $271 \pm 46.2$ & $84.1 \%$ \\
Protease & $69 \pm 0.9$ & $21.3 \%$ \\
Conjugase & $4.4 \pm 0.4$ & $1.4 \%$ \\
\hline
\end{tabular}

Initial green tea model sample (678 mg of EGCg/100 mL) was homogenized with 20 volumes of phosphate buffer, and sequentially treated with $\alpha$-amylase, protease, and conjugase as in reference (4). EGCg concentrations in the treated samples were determined by HPLC. Values are mean \pm SE, $n=5$.

bial growth at doses higher than 25-50 $\mu \mathrm{g} / \mathrm{mL}$, while C, EC and EGC did not show any inhibitory effect up to $200 \mu \mathrm{g} / \mathrm{mL}$ (Fig. 1). The inhibitory effect of EGCg was higher than that of $\mathrm{ECg}$, and complete inhibition was observed at $100 \mu \mathrm{g} / \mathrm{mL}$ of EGCg. The inhibitory concentration of EGCg was estimated to be higher than $10 \mu \mathrm{g} /$ $\mathrm{mL}$.

Effect of EGCg on tri-enzyme activities

Because EGCg is the major catechin of green tea, and showed the highest inhibitory effect on microbial growth, the effects of green tea catechins on the trienzyme activities were investigated using EGCg. EGCg inhibited the tri-enzyme activities in a dose-dependent manner. Significant inhibition was detected at doses higher than $750 \mu \mathrm{g} / \mathrm{mL}$ for $\alpha$-amylase, $1,000 \mu \mathrm{g} / \mathrm{mL}$ for protease, and $50 \mu \mathrm{g} / \mathrm{mL}$ for conjugase (Fig. 2). The Lineweaver-Burk plot showed that the mode of the EGCg inhibitory effect was similar between $\alpha$-amylase and protease, but slightly different for conjugase.

Decrease of EGCg during each analytical step

The green tea model sample $(678 \mathrm{mg}$ of $\mathrm{EGCg} / 100$ $\mathrm{mL}$ ) was diluted 20 times as is done in the assay, and the actual concentration of EGCg after each assay step was determined (Table 1). The concentration of EGCg in the sample markedly decreased following treatment by each of the three enzymes. The highest decrease was observed in the conjugase treatment. Furthermore, the EGCg sample concentration decreased to $1.1 \mu \mathrm{g} / \mathrm{mL}$ after addition to the culture medium in the microbial growth analysis step.

Folate analysis in green tea infusion with and without trienzyme treatments

Folate concentration in green tea infusion was increased by 4 fold by tri-enzyme treatment (Fig. 3). The folate concentration was increased by the addition of pteroyl- $\gamma$-L-glutamic acid, but not by pteroylhepta- $\gamma$-Lglutamic acid in green tea infusion without tri-enzyme treatment.

However, the green tea infusion with pteroylhepta- $\gamma$ L-glutamic acid showed an increase in folate concentration with tri-enzyme treatment. Recovery of pteroyl- $\gamma$ L-glutamic acid and pteroylhepta- $\gamma$-L-glutamic acid was $94 \%$ and $86 \%$, respectively. The actual EGCg concentra-

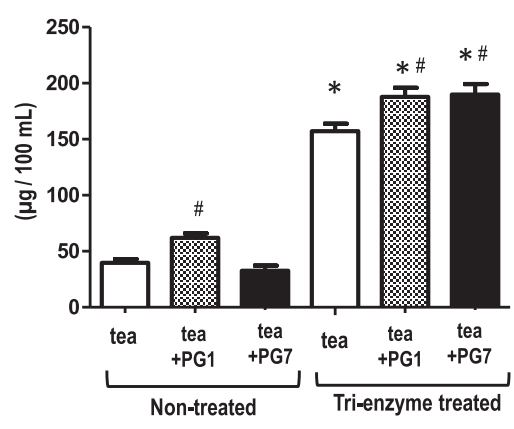

Fig. 3. Folate analysis in green tea infusion with and without treatment of tri-enzyme and addition of folate standard. Green tea infusion was applied to microbiological folate analysis with and without tri-enzyme treatment. As an folate standard, pteroyl- $\gamma$-L-glutamic acid (PG1) or pteroylhepta- $\gamma$-L-glutamic acid (PG7) was added to the green tea infusion at concentration of $31.1 \mu \mathrm{g} / 100 \mathrm{~mL}$ or $37.7 \mu \mathrm{g} / 100 \mathrm{~mL}$, Values are mean \pm SE, $n=5 .{ }^{*}$ Significant difference from the level without trienzyme treatment. "Significant difference from the level without addition of folate standard.

tion in the microbial growth analysis step was $0.65 \mu \mathrm{g} /$ $\mathrm{mL}$ in the non-treated sample, but an undetectable level in the tri-enzyme treated sample.

\section{Discussion}

Tea catechins, in particular EGCg, have been shown to inhibit various enzymes (10-12) as well as microbial growth (8). In the present study, EGCg inhibited three digestive enzymes and microbial growth, as demonstrated in the microbiological assay. A marked inhibitory effect of EGCg was observed on the growth of microorganism at a concentration of $10 \mu \mathrm{g} / \mathrm{mL}$. However, measurement of EGCg concentration after each step of the assay revealed that the EGCg concentration of the green tea model sample contained high EGCg in the microbial culture medium decreased to $1.1 \mu \mathrm{g} / \mathrm{mL}$, suggesting that EGCg is likely to show no practical interference on folate analysis in green tea. Lack of influence of EGCg on folate analysis in green tea was confirmed by the analysis of the actual concentration of EGCg and by the addition of folate standard in green tea infusion.

Among tea catechins, EGCg and ECg showed a significant inhibitory effect on microbial growth, while such an inhibitory effect was not observed in the other catechins that have no galloyl moiety. These results are consistent with a report by Sugita-Konishi et al. (8), who showed that among the tea catechins of green tea, EGCg and ECg inhibited the production and extracellular release of verotoxins from enterohemorrhagic E. coli EHEC at concentrations higher than $50 \mu \mathrm{g} / \mathrm{mL}$. In the present study, we only investigated the inhibitory effect of EGCg on the tri-enzyme treatment, because EGCg was observed to have the highest concentration among the tea catechins in green tea. However, Makimura et al. (10) reported that an inhibitory effect on collagenase activity was observed with EGCg and ECg at a concentration of $100 \mu \mathrm{g} / \mathrm{mL}$, but not with other tea catechins. Similar structure-associated inhibitory effects of tea cat- 
echins were reported in studies of pancreatic lipase (12) and $\alpha$-amylase (11). Therefore, it is highly unlikely that tea catechins without the galloyl moiety interfere with tri-enzyme digestion or microbial growth in the folate assay. It is well known that EGCg binds to casein and serum proteins, resulting in a decrease in its antioxidant (18) and anti-microbial activities (9). Proline groups in proteins are known to have a strong affinity for the hydroxyl group of EGCg (19). In the present study, a marked decrease in EGCg concentration was observed after the protease and conjugase treatments, which contained higher amounts of protein compared to the $\alpha$-amylase treatment. Therefore, the decrease in EGCg concentration observed during the tri-enzyme treatment may be due to the binding of EGCg to protein. The mode of inhibitory action by EGCg on the three enzymes was similar between $\alpha$-amylase and protease, but slightly different for the conjugase, which was a crude enzyme prepared from rat serum. Therefore, it is possible that the difference in the inhibitory mode of action may have been due to the protein content and possible impurities of the conjugase treatment.

Folate concentration in green tea infusion was increased to approximately 4 fold by tri-enzyme treatment, suggesting that folates in green tea exist as polyglutamate forms. The microorganism L. rhamnosus used in the folate assay mainly used the mono-glutamate form, but can used the di- and tri-glutamate form of folates (4). It has been shown that food folates exist in the 5-methly polyglutamate form (2). Therefore, folate in green tea would exist in the 5-methyl polyglutamate form as in the other foods. Further detailed study is needed to clarify the exact chemical structure of folates in green tea.

In conclusion, the present study demonstrated that tea catechins, in particular EGCg, have no practical impact on the folate analysis of green tea. In the microbiological assay, the treatment order by the three enzymes was slightly changed compared to previous reports $(5,6)$. In addition, the initial dilution of the analytical sample may change due to the folate content of the food samples. Knowledge of the inhibitory concentrations of EGCg for each enzyme and for the microbial growth identified in the present study may be helpful in such cases.

\section{Acknowledgments}

This study was financially supported by a Grand-inAid for Scientific Research (C) from the Japanese Society for the Promotion of Science (JSPS) (No. 25234567).

\section{REFERENCES}

1) Pitkin RM, Allen LH, Bailey LB, Bernfield M, De Walts P, Green R, Mc Cormick D, Russell RM, Shane B, Zeisel SH, Rosenberg IH, ed. 1998. Folate. In: Dietary Reference Intakes for Thiamin, Riboflavin, Niacin, Vitamin $\mathrm{B}_{6}$, Folate, Vitamin $\mathrm{B}_{12}$, Pantothenic Acid, Biotion, and Choline. National Academic Press, Washington, D.C.

2) Konings EJ, Roomans HH, Dorant E, Goldbohm RA, Saris WH, van den Brandt PA. 2001. Folate intake of the Dutch population according to newly established liq- uid chromatography data for foods. Am J Clin Nutr $\mathbf{7 3 :}$ 765-776.

3) Arcot J, Shrestha A. 2005. Folate: methods of analysis. Trends Food Sci Technol 16: 253-266.

4) Tamura T, Shin YS, Williams MA, Stokstad EL. 1972. Lactobacillus casei response to pteroylpolyglutamates. Anal Biochem 49: 517-521.

5) Aiso K, Tamura T. 1998. Trienzyme treatment for food folate analysis: optimal $\mathrm{pH}$ and incubation time for alpha-amylase and protease treatment. J Nutr Sci Vitaminol 44: 361-370.

6) Hyun TH, Tamura T. 2005. Trienzyme extraction in combination with microbiologic assay in food folate analysis: an updated review. Exp Biol Med (Maywood) 230: $444-454$.

7) Imaeda N, Goto C, Tokudome Y, Ikeda M, Maki S, Tokudome S. 2002. Folate intake and food sources in Japanese female dietitians. Environ Health Prev Med 7: 156-161.

8) Sugita-Konishi Y, Hara-Kudo Y, Amano F, Okubo T, Aoi N, Iwaki M, Kumagai S. 1999. Epigallocatechin gallate and gallocatechin gallate in green tea catechins inhibit extracellular release of Vero toxin from enterohemorrhagic Escherichia coli 0157: H7. Biochim Biophys Acta 1472: 42-50.

9) Yoda Y, Hu ZQ, Zhao WH, Shimamura T. 2004. Different susceptibilities of Staphylococcus and Gram-negative rods to epigallocatechin gallate. J Infect Chemother 10: 55-58.

10) Makimura M, Hirasawa M, Kobayashi K, Indo J, Sakanaka S, Taguchi T, Otake S. 1993. Inhibitory effect of tea catechins on collagenase activity. J Periodontol 64: 630-636.

11) Yilmazer-Musa M, Griffith AM, Michels AJ, Schneider E, Frei B. 2012. Grape seed and tea extracts and catechin 3-gallates are potent inhibitors of alpha-amylase and alpha-glucosidase activity. J Agric Food Chem 60: 8924-8929.

12) Nakai M, Fukui Y, Asami S, Toyoda-Ono Y, Iwashita T, Shibata H, Mitsunaga T, Hashimoto F, Kiso Y. 2005. Inhibitory effects of oolong tea polyphenols on pancreatic lipase in vitro. J Agric Food Chem 53: 4593-4598.

13) Bernfeld P. 1955. Amylases, $\alpha$ and $\beta$ methods. Methods Enzymol 1: 149-158.

14) Anson ML. 1938. The estimation of pepsin, trypsin, papain, and cathepsin with hemoglobin. J Gen Physiol 22: 79-89.

15) Unno T, Sagesaka YM, Kakuda T. 2005. Analysis of tea catechins in human plasma by high-performance liquid chromatography with solid-phase extraction. J Agric Food Chem 53: 9885-9889.

16) Hasoun LZ, Bailey SW, Outlaw KK, Ayling JE. 2013. Effect of serum folate status on total folate and 5-methyltetrahydrofolate in human skin. Am J Clin Nutr 98: $42-48$.

17) Umegaki K, Sugisawa A, Yamada K, Higuchi M. 2001. Analytical method of measuring tea catechins in human plasma by solid-phase extraction and HPLC with electrochemical detection. J Nutr Sci Vitaminol 47: 402-408.

18) Lorenz M, Jochmann N, von Krosigk A, Martus P, Baumann G, Stangl K, Stangl V. 2007. Addition of milk prevents vascular protective effects of tea. Eur Heart J $\mathbf{2 8}$ : 219-223.

19) Arts MJ, Haenen GR, Wilms LC, Beetstra SA, Heijnen CG, Voss HP, Bast A. 2002. Interactions between flavonoids and proteins: effect on the total antioxidant capacity. J Agric Food Chem 50: 1184-1187. 